DOI: https://doi.org/10.34069/AI/2021.47.11.18 How to Cite:

Sarybaieva, G., Panova, L., Gramatskyy, E., Panov, A., \& Pahlevanzade, A. (2021). International legal personality in public and private law: problems of theory and practice. Amazonia Investiga, 10(47), 180-189. https://doi.org/10.34069/AI/2021.47.11.18

\title{
International legal personality in public and private law: problems of theory and practice
}

\section{Міжнародна правосуб'сктність у публічному і приватному праві: проблеми теорії та практики}

Received: October 27, 2021

Accepted: November 28, 2021
Written by:

Ganna Sarybaieva ${ }^{78}$

https://orcid.org/0000-0003-4492-956X

Liydmyla Panova ${ }^{79}$

https://orcid.org/0000-0002-1393-8626

Ernest Gramatskyy ${ }^{80}$

https://orcid.org/0000-0003-1260-2888

Alen Panov ${ }^{81}$

https://orcid.org/0000-0002-8944-0533

Alborz Pahlevanzade ${ }^{82}$

https://orcid.org/0000-0002-2807-7320

\begin{abstract}
At the present stage of the development of international relations, an important aspect is the specification of the rights and obligations of the subjects of international law, which are elements of international legal personality, which is subject to multifaceted study. The research of its problematic elements is fundamental to improving the rules of international law in general and domestic law in particular. The work aims to study and identify problems of theory and practice of international legal personality in public law. The object of research is international legal personality in public law. The subject of the research is problematic aspects of the theory and practice of international legal personality in public law. The following methods were used in the study: observation, historical method, method of analysis, comparison, generalization, the system method, method of analysis of normative documents. As a result of the research, the institute of international legal personality, in general, was analyzed, its peculiarities and problematic aspects were determined.
\end{abstract}

\begin{abstract}
Анотація
На сучасному етапі розвитку міжнародних відносин важливим аспектом $\epsilon$ конкретизація прав та обов'язків суб'єктів міжнародного права, що $\epsilon$ елементами міжнародної правосуб' єктності, яка піддається багатоаспектному вивченню. Вивчення іiі проблемних елементів має основоположне значення для вдосконалення норм міжнародного права в цілому та внутрішньодержавних норм зокрема. Метою роботи є дослідження та виявлення проблем теорії та практики міжнародної правосуб'єктності у публічному праві. Об'єктом дослідження є міжнародна правосуб'єктність у публічному праві. Предметом дослідження є проблемні аспекти теорії та практики міжнародної правосуб' єктності у публічному праві. У дослідженні було використано наступні методи: спостереження, історичний метод, метод аналізу, порівняння, узагальнення, системний метод, метод аналізу нормативних документів. У результаті дослідження було проаналізовано інститут міжнародної
\end{abstract}

\footnotetext{
${ }^{78}$ Doctor of Legal Sciences, Associate Professor of the Department of Administrative and Financial Law of the National University "Odesa Law Academy", Odesa, Ukraine.

${ }^{79}$ Ph.D., Associate Professor of Civil Law Department, Taras Shevchenko National University of Kyiv, Kyiv, Ukraine.

${ }^{80}$ Ph.D., Associate Professor of Civil Law Department, Taras Shevchenko National University of Kyiv, Kyiv, Ukraine.

${ }^{81}$ Ph.D., Associate Professor, Candidate of Historical Sciences, Head of the Department of International Politics, Uzhhorod National University, Ukraine.

${ }^{82} \mathrm{Ph}$.D., Associate Professor of Department of International Law and comparative Law, Head of the preparatory department for foreign students of International Humanitarian University, Odesa, Ukraine.
} 


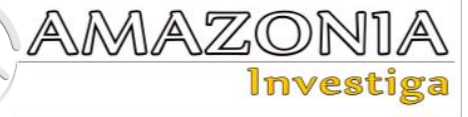

Keywords: international legal personality, public law, public international law, subjects of international law.

\section{Introduction}

Turning to the general theory of law, public law is a subsystem of law, which consists of rules governing relations related to the exercise of public authority in the interests of state and local government through the imperative method of legal regulation.

Public law includes substantive public law branches (constitutional, administrative, criminal, financial law, etc.) and procedural public law branches (criminal procedural, civil procedural, administrative procedural law, etc.) (Petryshyn, 2015).

The field of public law also includes international law, which is most accurately called international public law. The latter is also used in international instruments such as the Charter of the International Court of Justice, the UN General Assembly Resolution on the Progressive Development of International Law, and its Codification of 11 December 1946, which points to the need for careful and comprehensive study of all that has already been achieved in the development of international law and its codification, as well as "study of projects and activities of formal and informal institutions that focus on promoting progressive development and public and private international law" (Telipko, \& Ovcharenko, 2010).

The concept of international legal personality refers to the scope of public international law, as it is inherent in the holders of certain international rights and obligations arising following general rules or regulations of international law.

International legal personality is a property of the subjects of international law, which includes the following elements: international legal capacity, international legal capacity, and international tort (Butkevich, Mytsyk, \& Zadorozhny, 2002), which are both its hallmarks. Thus, international legal capacity is the ability to exercise rights and responsibilities, international legal capacity consists of the right to have rights and responsibilities, and is the same for all participants in international relations, although

правосуб'єктності в цілому, визначено іï особливості та проблемні аспекти.

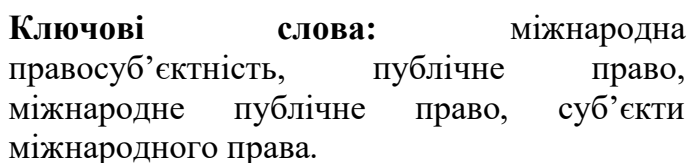
міжнародного права.

the number of rights and responsibilities of individual entities may be different, international tort - the ability to bear legal responsibility for their actions. In this context, legal capacity and capacity are inseparable concepts for subjects of international law. However, there have been cases in world history when, while retaining the status of a subject of international law, the state has become completely or partially incapable. Thus, during the Second World War, the states occupied by Hitler's government retained their legal capacity, and their capacity was exercised by their governments in exile.

It should be noted that in addition to the above features, the features of international legal personality include the ability to participate in the creation of international law (Bekyashev, 2001).

The research of its problematic elements is fundamental to improving the rules of international law in general and domestic law in particular. The work aims to study and identify problems of theory and practice of international legal personality in public law.

\section{Theoretical Framework or Literature Review}

Such scholars as Bekyashev (2001), Telipko, and Ovcharenko (2010), Butkevich, Mytsyk, \& Zadorozhny (2002), Baimuratov (2004), Skorokhod (2012), Timchenko and Kononenko (2012) were engaged in the study of international legal personality, Stepanenko (2016), Vavilova, Sivokha, and Leonov (2016), Baraev (2011), Tsymbrivsky (2018), Lukashuk (2015), Kosyuk (2014), Nesterenko (2011), Denisova (2014), Zhukorska (2013), Ferdross (1969), and Zozulya (2018), whose works were used in writing this work.

The theoretical basis for the analysis of international legal personality in public law were textbooks on international law, the authors of which express their views on the phenomena of international space. Thus, Bekyashev (2001) describes in detail the law of international organizations, UN law, integration law. The book is based on the analysis of international 
documents, decisions of the UN International Court of Justice, and other judicial bodies. Authors Telipko, and Ovcharenko (2010) reveal in detail and systematically the main institutions and branches of modern international public law. Moreover, Lukashuk (2015) gives an expanded interpretation of the principles of international law. Baimuratov provides an extensive description of the subjects of international law, which became the basis for the characterization of their legal personality. The use of textbooks by such authors as Butkevich, Mytsyk, \& Zadorozhny (2002), Timchenko and Kononenko (2012), Ferdross (1969) allowed to characterize the debatable elements of international legal personality, in particular the place of the individual in the system of subjects of international law.

The scientific work of Vavilova, Sivokha, and Leonova (2016) considers the contradictions associated with the relationship between the force of law and the law of force, which is in how legitimate the use of force in the system of international relations. Different approaches to justifying force and the new conditions that affect it are also considered.

Tsymbrivsky (2018) analyzes the legal content of the principles of territorial integrity and inviolability of borders and the peculiarities of the implementation of these norms in modern international legal relations.

Further, Baraev (2011) explores some aspects of the problem of non-use of the force and threat of force in the modern period, emphasizes its importance in forming an effective system of global and regional security, as well as international legal position in these areas of international relations.

The issue of the international legal personality of international organizations and individuals has been studied in the works of such authors as Skorokhod (2012), Nesterenko (2011), Denisova (2014), Zhukorska (2013), and Zozulya (2018).

Despite a fairly wide range of research on the issue of international legal personality, the question of the place of an individual in international relations, his responsibility remains open; issues of the tort of international organizations, namely the legal mechanism of prosecution, regulatory consolidation of international responsibility of international organizations; theoretical improvement of legal capacity and capacity of states, state-like entities.

\section{Methodology}

The value of the methodological basis of the study lies in the use of such methods of scientific knowledge that will allow to fully disclose the topic of the work. The methodology is a set of methods of scientific knowledge, which are used in this paper as follows:

- $\quad$ using the method of observation, generalized data were obtained, which allowed to legitimately reflect the characteristics of the object of study. Thus, the conceptual apparatus of international legal personality, its types, properties were determined; the subjects of international relations, principles of international law are singled out;

- the method of comparison, which consists in establishing similarities and differences between objects and phenomena of reality, as well as establishing common in the compared objects, allowed to compare the legal personality of international law and highlight problematic aspects of theoretical and practical nature, such as regulatory imperfections regulation of the rights and obligations of states and state-like entities, the issue of the tort of international organizations and individuals;

- historical method - a method of scientific research, which was utilized to provide examples that confirm the practice of implementing the principles of international law, which has an impact on international legal personality;

- the application of the method of generalization allowed to distinguish the classification of subjects of international law, the consideration of the legal personality of which created the basis for achieving the goal of this study. This method also helped to distinguish between theoretical and practical aspects of international legal personality.

- the system method has created opportunities for consistent presentation of the material, to identify thematic blocks that contribute to a better perception of the information presented in the study. In addition, the method helped to determine the conclusions of each of the studied elements, namely the subjects of international legal relations, which have legal personality;

- The method of analysis is necessary for any study because only by decomposing the available information material into components, it is possible to find the most important statements that are relevant to the topic of the work. In the context of this 


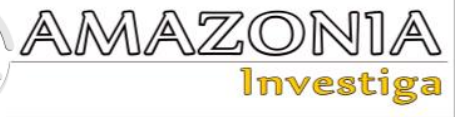

study, many sources were used, namely scientific articles, textbooks, international norms, and practical data of international relations, the analysis of which contributed to the detailed justification of the selection of problematic aspects of international legal personality;

- The method of analysis of normative documents is of great importance for the study of international legal personality through the prism of international documents, which in this paper is a fundamental aspect of highlighting the points of discussion of the implementation of international legal personality.

\section{Results and Discussion}

To determine the features and problematic aspects of international legal personality, it is necessary to identify subjects of international law.
For a long time, the state was considered the only subject of international law. In the process of evolution of international law, the range of holders of rights and responsibilities is expanding, which is explained by the search for international law and order and stability (Antonovich, 2011). The most generalized classification of subjects of international law can be defined as follows:

1) by participants in international relations: states, state-like entities, nations (peoples), international organizations, individuals.

2 ) in the order of formation: primary and derivative. The primary ones are states (such entities inevitably come into contact with each other, establishing rules of interaction, which are enshrined in international acts and become legally binding), the secondary international organizations (they are created by states and given rights and powers depending from the will of their creators).

Table 1.

Types of international legal personality by Baimuratov (2004) and Skorokhod (2012).

\begin{tabular}{ll}
\hline General & $\begin{array}{l}\text { The ability of subjects by virtue of their existence (ipso facto) to be } \\
\text { bearers of rights and obligations in international relations }\end{array}$ \\
\hline \multirow{3}{*}{ Branches } & $\begin{array}{l}\text { The ability of subjects of international law to be participants in a } \\
\text { particular field of international relations. International intergovernmental } \\
\text { organizations, such as UNESCO, have such legal personality } \\
\text { Ability to be a member of a small circle of relations within a particular } \\
\text { branch of international law. Such legal personality is possessed, for } \\
\text { example, by individuals and international non-governmental } \\
\text { organizations. }\end{array}$ \\
\hline
\end{tabular}

Legal personality of the state as the primary subject of international law

States are subjects of international law that play the most important role in international relations. This is due to the fact that they are sovereign entities and on equal legal grounds enter into relations with each other, create international norms, and act as guarantors of their implementation. States also have universal legal capacity, which has no restrictions on the subject of legal regulation and time, which distinguishes them from other subjects of international law (Timchenko, \& Kononenko, 2012).

The general principles of public international law include:

- the principle of sovereign equality of states. The principle is as follows: states are obliged to respect each other's equality, the sovereign rights of states; each state has the right to freely develop its political, economic, social, and cultural systems, to establish its own laws, have equal fundamental rights and responsibilities, they are obliged to respect each other's right to determine and exercise their relations with other states in accordance with norms of international law, each state has the right to participate in international organizations and treaties, each state is obliged to perform its duties under international law in good faith.

The principle of state sovereignty has a certain inconsistency in its content. Thus, the UN Charter has given five states the rights that other members do not have, namely the permanent members of the Security Council, who have the right to veto, which greatly expands their influence on the development of international relations. This situation is explained by the events of World War II when countries such as Britain, Russia, China, the USA, France were awarded a place of honor for their great 
contribution to the defeat of fascism. Today this factor has lost its relevance.

It is also considered necessary and expedient to develop a concretization and codification of the provisions of the principle of non-use of force and the threat of use of force. History has known the case of initiating the conclusion of the World Treaty on the Non-Use of Force in International Relations, but it has not been implemented (Baraev, 2011);

- the principle of territorial integrity of states and the principle of inviolability of state borders. The principle of territorial integrity as a separate system of international principles is enshrined in the "Final Act of the Conference on Security and Cooperation in Europe" of August 1, 1975 (United Nations, 1975). Chapter IV of this document is entitled "Territorial Integrity of the State". It stipulates that States will respect the territorial integrity of each of the participating States. The provisions of this document also stipulate that member states will refrain from turning the territory of the country into an object of military operation or other direct and indirect measures of force to violate international law. No occupation will be recognized as legitimate.

- the content of the principle of inviolability of state borders is disclosed in Chapter III of the Final Act of the Conference on Security and Cooperation in Europe of 1 August 1975, entitled "Inviolability of Borders". Thus, the participating States consider inviolable all the borders of the participating states, as well as the borders of all European states, and, therefore, they will refrain from any encroachment on these borders, States Parties shall refrain from any claim or action aimed at usurping part or all of the territory of any State Party.

- the principle of peaceful settlement of international disputes. The principle obliges states to settle disputes peacefully, giving them the right to choose such means.

The Hague Conventions on the Peaceful Settlement of International Disputes of 1899 and 1907 recommend that member states resort to peaceful services or mediation, set up commissions of inquiry, and use the institution of arbitration to resolve the conflict. The latter is considered effective in resolving legal issues, especially in the interpretation or application of international conventions (Gusarev, \& Tikhomirov, 2008), in its ruling on the lawfulness of the use of force (Yugoslavia v. The
United States), the UN International Court of Justice emphasized that the parties to the conflict should not aggravate the situation during its peaceful settlement (United Nations, 2002);

- the principle of non-interference in internal affairs. The principle is the prohibition of interfering in domestic affairs. This provision is clarified by the norms of international documents, namely the Helsinki Document of 1992 (the above issues are of legitimate interest to all states and are not exclusively the affairs of individual states (Helsinki Summit, 1992), the Universal Declaration of Human Rights of 1948 (universal recognition of inalienable human rights) is the basis of freedom, justice and universal peace (United Nations, 1948).

It should be noted that the principle of noninterference in internal affairs has an exception, as stated in the UN Charter, which stipulates that the principle of non-interference does not preclude the application of coercive measures to the state by the Security Council. Experience shows that military actions of an individual state or group of states, which were carried out under the guise of humanitarian intervention, have a positive effect. They are contrary to international law and condemned by the international community. Thus, US intervention in Grenada and Panama was condemned by both the United Nations and the Organization of American States. The International Court of Justice has refused to discuss the possibility of legalizing humanitarian intervention.

The UN has the right to use force to resolve armed conflict within the country, which must be decided by the Security Council;

- the principle of universal respect for human rights. This principle plays a major role not only in domestic law but also in international law. It became especially important for the international community after the Second World War. It was in the post-war period that the provisions on man as the highest value began to be actively developed. Thus, the Universal Declaration of Human Rights of December 10, 1948 (United Nations, 1948), the International Covenant on Civil and Political Rights, the International Covenant on Economic, Social and Cultural Rights of December 16, 1966 (General Assembly, 1966), and others were adopted. In addition, the UN Charter itself obliges states to affirm faith in fundamental human rights, to cooperate internationally in the 


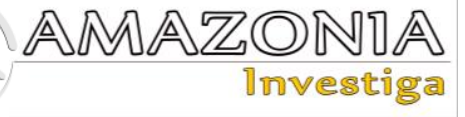

promotion and development of respect for human rights and fundamental freedoms (United Nations, 1945);

- the principle of self-determination of peoples and nations. First of all, it should be stated that the subjects defined by the UN Charter in the context of this principle are quite large and integrated communities. In this regard, we should also pay attention to the ethnic, religious minority, which also has the right to some independence, namely the right to cultural autonomy, to respect their interests within the state.

UN practice understands the principle of selfdetermination as the right of colonial peoples to independence from metropolises. This understanding was enshrined in the Declaration of Independence of the Colonial States and Peoples of 1960 (General Assembly, 1960). The international document also emphasizes that any attempt to completely or partially violate the national unity and territorial integrity of the country is incompatible with the goals and principles of the UN Charter. Thus, the possibility of abusing the principle of selfdetermination was limited by the principle of territorial integrity.

Theorists and practitioners of political science and international law are in favor of a more declarative approach and limiting the application of the principle of self-determination. It should be noted that the position of the United Nations and its structures, in particular the UN International Court of Justice, which at the same time resolves interstate territorial disputes, tends to limit the implementation of the principle of self-determination and preservation of territorial integrity (Kosyuk, 2014).

the principle of cooperation. This principle obliges states to cooperate regardless of their differences in economic, social, and political systems to maintain international peace and security. The obligation of international cooperation presupposes observance of the norms of international law and the UN Charter.

To legally oblige the state to cooperate with another is seen as a difficult task, as well as to incite to friendship. Therefore, it is seen to perceive the provisions of this principle as an idea that permeates all international principles;

- the principle of conscientious fulfillment of international obligations is the legal basis of international law. It arose simultaneously with international law and took the form of a "pacta sunt servanda" (treaties must be fulfilled). The importance of this principle also lies in the fact that international treaties concluded between states have an impact on national law. Through the implementation of international treaties, states develop their legislation, bring it into line with generally accepted principles and norms of international law.

\section{Legal personality of international organizations}

Not all international organizations are subject to international law. Thus, the subjects of international relations are international intergovernmental organizations, which are created by the primary subjects of international law - states. The peculiarities of an international intergovernmental organization are that it is created based on an international agreement, has no territory and sovereignty, has a permanent or regular nature of the activity, the main method of its activities - multilateral negotiations, decisionmaking by voting or consensus. The international legal personality of an international intergovernmental organization is limited by its statute, which determines the goals of its creation, provides for the existence of organizational structure, determines the competence of statutory bodies and officials of the organization, organizational and legal forms of its activities. An international intergovernmental organization also has a special legal capacity because it cannot be a party to cases before the UN International Court of Justice. Unlike international intergovernmental organizations, international non-governmental (public organizations) are founded by individuals or legal entities, their statutes are not international treaties, but they have special legal personality, as they are given consultative international legal status with international intergovernmental organizations. Examples of international non-governmental organizations are the World Federation of Trade Unions, the International Union of Local Authorities, etc. Their total number exceeded 4 thousand (Baimuratov, 2004).

The responsibility of an international organization will arise from the fact that its bodies and officials violate the statutory provisions of the organization and the general rules of international law. In UN practice, there have been cases in which the organization has accepted responsibility for actions committed by members of the UN armed forces. In this regard, we can mention the UN agreements concluded in 1965-1967 with some states to compensate for 
the damage caused to the citizens of these countries and their property during the operations of the UN armed forces in the Congo.

Currently, in international practice, the problem of liability of international organizations is solved mainly in the field of compensation for material damage. Thus, in some agreements on space - the Treaty on the Principles Governing on the Exploration and Use of Outer Space, including the Moon and Other Celestial Bodies (General Assembly, 1967); Agreement on the Rescue of Astronauts, the Return of Astronauts and the Return of Objects Launched into Outer Space (General Assembly, 1968); The 1972 Convention on International Liability for Damage Caused by Space Objects (General Assembly, 1972) lays down rules establishing the liability of international organizations and participating States for damage resulting from space activities.

On August 5, 2011, at the 63rd session of the Commission on International Law, the Draft on the Responsibility of International Organizations was adopted. According to the Project, the international organization is obliged to restore the state that existed before the commission of an internationally illegal act, i.e. to carry out restitution to the extent possible (Zhukorska, 2013). Restitution is compensation for material damage in kind.

Legal personality of state-like entities (quasistates)

Quasi-state or state-like entities in modern international law include free cities (currently non-existent), the Vatican, and the Order of the Knights of Malta. The status of such entities is usually determined in international treaties.

Characteristic features of the international legal personality of the state of such entities are:

- created based on an international treaty, for example, an agreement concluded between the Holy See (as the Vatican is officially called in international instruments) and the Italian monarchy in 1929 (Lateran Pacts) was the beginning of the Vatican's independent existence. In 1984, a new agreement (concordat) was concluded between the Vatican and the Italian Republic on the status of the Holy See, which confirmed the basic provisions of the Lateran Treaties of 1929. The 1984 agreement is still in force;

- have their territory, legislation, citizenship;
- have the right to participate in international relations, to establish permanent representations in other states.

\section{Legal personality of an individual}

It should be remarked that the attribution of an individual to the system of subjects of international law is a debatable issue and needs further study. Thus, in the science of international law, there is no unity on the legal status of an individual in international legal relations. For example, the scholar Lukashuk believes that human rights and responsibilities can not be limited by international treaties or domestic acts and relate to the general theory of natural law (Lukashuk, 2005).

The problem of determining the legal status of an individual as a subject of international law is the existence of opposing views on this. Thus, there are the following arguments in support of the claim that a natural person is a subject of international law:

- human rights and responsibilities are enshrined in international instruments such as the International Covenant on Economic, Social and Cultural Rights of 1966, the Universal Declaration of Human Rights of 1948, the International Covenant on Civil and Political Rights of 1966, and many others:

- natural persons must be able to act as a party to the state court. According to the European Convention on Human Rights of 1950, everyone has the right to apply to the European Court of Human Rights if he considers that his rights have been violated and if he has exhausted all possible means of defending his right at the national level (Council of Europe, 1950).

Another feature of the jurisdiction of the International Criminal Court is that its implementation is possible only after bringing to justice by the national judicial authorities of the state.

Thus, it can be concluded that there is some inconsistency in the theoretical basis and practical implementation of international legal personality, which is seen in the principles of international law governing the rights and obligations of subjects of international law. The practice of international relations shows the need for more detailed regulation of such elements of legal personality as a tort (especially in the field of responsibility of international organizations), 


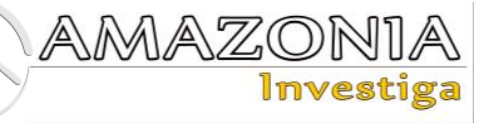

legal capacity, and capacity (in terms of expanding regulations and detailed interpretation of possible behavior in international relations).

\section{Conclusions}

Peculiarities and problematic aspects of the legal personality of subjects of international law are to clarify and analyze its content. Therefore, the international legal personality of states is related to the normative principles of international law. Summarizing their analysis, we can state the following in general:

- the principle of cooperation is voluntary, which is associated with the impossibility of forcing the state to cooperate with another one;

- only those nations that do not have their nation-states, such as the Palestinians or the Kurds, have the right to self-determination. At the same time, the right of national minorities to defend their national and cultural identity should not be confused with the right of peoples to self-determination;

- the international legal personality of the state and the individual are closely linked, as the latter cannot exist outside the jurisdiction of a particular country. Although international law focuses on the activities of the main actors - states, but man and his rights are a priority element;

- the possibility of interfering in the internal affairs of the state must be fully justified and comply with international law. In the context of the legal personality of states, its reasonable use and observance can be seen;

- the principle of peaceful settlement of international disputes is one of the most important means of maintaining international peace and ensuring the peaceful coexistence of states. However, as practice shows, states still use weapons to resolve their disputes, which leads to human losses, deteriorating economies of these states, and deteriorating international relations in general;

Detailed regulation of the principle of peaceful settlement of disputes by concluding an international agreement is considered expedient;

- the existence of the principles of territorial integrity of states and the principle of inviolability of state borders does not mean that borders are something frozen and not subject to any change;
- a need for a clear regulation of norms that would regulate the conditions of use of force in the case of self-defense;

- the problem of the principle of peaceful settlement of international disputes is the existence of limited equality of states.

As for the international legal personality of international organizations, as they increase their influence on international relations, they must be held accountable for their actions.

In the science of international law, the question of granting an individual the status of a subject of international relations remains open. It can also be concluded that there is no doubt about the possibility of the existence of individual responsibility in modern international criminal law. However, the implementation of the principle of individual criminal responsibility for committing international crimes has specific features, including an unjustifiably limited range of objective grounds for bringing individuals to international responsibility with the participation of the International Criminal Court; the existence of a permitting nature of the implementation of the International Criminal Court of its jurisdiction; application of the principle of supplementation in the exercise of its jurisdiction by the International Criminal Court. Thus, today there is an urgent need to improve the mechanism for implementing the principle of individual responsibility in international criminal law with the participation of the International Criminal Court.

\section{Bibliographic references}

Antonovich, M. (2011). International law. Kyiv: Yurinkom Inter.

Baimuratov, M.A. (2004). Public international law. Kyiv: Istina.

Baraev, V.M. (2011). Problems of compliance with the principle of non-use of force in international relations (doctoral thesis). Dnepropetrovsk National University, Dnepro. Recovered from http://apnl.dnu.in.ua/1_2011/4.pdf

Bekyashev, K.A. (2001). International public law. Moscow: Prospect.

Butkevich, V.G., Mytsyk, V.V., \& Zadorozhny O.V. (2002). International law. Fundamentals of theory. Kyiv: Lybid. Recovered from http://law.inf.ua/\%D0\%BC\%D1\%96\%D0\% B6\%D0\%BD\%D0\%B0\%D1\%80\%D0\%BE $\% \mathrm{D} 0 \% \mathrm{~B} 4 \% \mathrm{D} 0 \% \mathrm{BD} \% \mathrm{D} 0 \% \mathrm{~B} 5-$ $\% \mathrm{D} 0 \% \mathrm{BF} \% \mathrm{D} 1 \% 80 \% \mathrm{D} 0 \% \mathrm{~B} 0 \% \mathrm{D} 0 \% \mathrm{~B} 2 \% \mathrm{D}$ $0 \% \mathrm{BE}-$ 
$\% \mathrm{D} 0 \% \mathrm{BE} \% \mathrm{D} 1 \% 81 \% \mathrm{D} 0 \% \mathrm{BD} \% \mathrm{D} 0 \% \mathrm{BE} \% \mathrm{D}$ $0 \% \mathrm{~B} 2 \% \mathrm{D} 0 \% \mathrm{~B} 8-$

$\% \mathrm{D} 1 \% 82 \% \mathrm{D} 0 \% \mathrm{~B} 5 \% \mathrm{D} 0 \% \mathrm{BE} \% \mathrm{D} 1 \% 80 \% \mathrm{D} 1$ $\% 96 \% \mathrm{D} 1 \% 97$

$\% \mathrm{D} 0 \% \mathrm{~B} 1 \% \mathrm{D} 1 \% 83 \% \mathrm{D} 1 \% 82 \% \mathrm{D} 0 \% \mathrm{BA} \% \mathrm{D}$ 0\%B5\%D0\%B2\%D0\%B8\%D1\%87.html

Council of Europe. (1950). Convention for the Protection of Human Rights and Fundamental Freedoms. Recovered from https://zakon.rada.gov.ua/laws/show/995_00 4\#Text

Denisova, D.O. (2014). Responsibility of international organizations. Odessa: Phoenix.

Ferdross, A. (1969). International Law. Moscow: Foreign literature. Recovered from http://lawlibrary.ru/izdanie13096.html

General Assembly. (1960). Declaration on granting independence to colonial states and peoples. $\quad$ Recovered from https://zakon.rada.gov.ua/laws/show/995_28 0\#Text

General Assembly. (1966). International Covenant on Civil and Political Rights, the International Covenant on Economic, Social and Cultural Rights. Recovered from https://www.ohchr.org/en/professionalintere st/pages/cescr.aspx

General Assembly. (1967). Treaty on the Principles Governing on the Exploration and Use of Outer Space, including the Moon and Other Celestial Bodies. Recovered from https://www.unoosa.org/oosa/en/ourwork/sp acelaw/treaties/introouterspacetreaty.html

General Assembly. (1968). Agreement on the Rescue of Astronauts, the Return of Astronauts and the Return of Objects Launched into Outer Space. Recovered from https://www.unoosa.org/oosa/en/ourwork/sp acelaw/treaties/introrescueagreement.html

General Assembly. (1972). Convention on International Liability for Damage Caused by Space Objects. Recovered from https://www.unoosa.org/oosa/en/ourwork/sp acelaw/treaties/introliability-

convention.html

Gusarev, S.D., \& Tikhomirov, O.D. (2008). Legal deontology (Fundamentals of legal activity). Kyiv: Znannya. Recovered from http://194.44.152.155/elib/local/sk673275.pd $\mathrm{f}$

Council of Europe. (1992). Declaration of the Helsinki Document of 1992 "The Challenge of a Time of Change". Recovered from https://zakon.rada.gov.ua/laws/show/994_11 5\#Text

Kosyuk, T.P. (2014). Actual aspects of interpretation and implementation of the principle of self-determination of peoples. Scientific records: Political Science, 160,
17-22. Recovered from https://core.ac.uk/download/pdf/149241498. pdf

Lukashuk, I. I. (2015). International law. General part. Moscow: Walters Kluver. ISBN 5'466'00103'1

Nesterenko, S.S. (2011). Codification of norms on the responsibility of international organizations. Actual problems of state and law, 59, 64-69. Recovered from http://nbuv.gov.ua/UJRN/apdp_2011_59_8

Petryshyn, O.V. (Ed.). (2015). Theory of State and Law. Kharkiv: Pravo. Recovered from https://pravoizdat.com.ua/image/data/Files/126/1-30.pdf

Skorokhod, G.M. (2012). Institute of International Legal Entity in the System of Modern International Law. Scientific Bulletin of Lviv State University of Internal Affairs, 3, 122-129. Recovered from https://www.lvduvs.edu.ua/documents_pdf/v isnyky/nvsy/03_2012/12sgmsmpp.pdf

Stepanenko, K.V. (2016). Synopsis of lectures on the discipline of International Public Law. Dnipro: DDUVS.

Telipko, V.E., \& Ovcharenko, A.S. (2010). International public law. Kyiv: Center for Educational Literature. Recovered from https://library.nlu.edu.ua/POLN_TEXT/CU L/26_2-Mizhnarodne_publichne_pravoTelipko2010.pdf

Timchenko, L.D., \& Kononenko, V.P. (2012). International law. Kyiv: Znannya. Recovered from https://westudents.com.ua/knigi/436mjnarodne-pravo-timchenko-ld-.html

Tsymbrivsky, T.S. (2018). Adherence to the principles of territorial integrity and inviolability of borders in international law (doctoral thesis). Taras Shevchenko National University of Kyiv, Kyiv. Recovered from https://er.ucu.edu.ua/bitstream/handle/1/930/ Tsymbrivskyy_Compliance_With_Principle s.pdf? sequence $=1 \&$ is Allowed $=y$

United Nations. (1945). Charter of the and Statute of the International Court of Justice. Recovered from https://zakon.rada.gov.ua/laws/show/995_01 $0 \#$ Text

United Nations. (1948). Universal Declaration of Human Rights. Recovered from https://zakon.rada.gov.ua/laws/show/995_01 5\#Text

United Nations. (1975). Final Act of the UN Conference on Security and Cooperation in Europe. Recovered from https://zakon.rada.gov.ua/laws/show/994_05 5\#Text

United Nations. (2002). A summary of judgments, advisory opinions and orders of 
the International Court of Justice. Recovered from

https://legal.un.org/icjsummaries/documents/ russian/st_leg_serf1_add2.pdf

Vavilova, N., Sivokha, I., \& Leonova, V. (2016). The right of states to use force in international relations. Center for Military and Strategic Studies of the National University of Defense of Ukraine named after I. Chernyakhovsky, 1, 18 - 23. Recovered from http://znpcvsd.nuou.org.ua/article/view/127716/12252 9
Zhukorska, Ya. M. (2013). Responsibility of international organizations for violation of international legal obligations: current status. Journal of Kyiv University of Law, 2, 356-360. Recovered from http://nbuv.gov.ua/UJRN/Chkup_2013_2_87

Zozulya, K.T. (2018). Features of individual responsibility in international criminal law. Legal Doctrines, 1, 256-260. Recovered from http://dspace.onua.edu.ua/bitstream/handle/1 $1300 / 6346 /$ Zozulya.pdf? sequence $=1 \&$ isAllo wed=y 